\title{
Animal performance and diet quality as influenced by burn- ing on tallgrass prairie
}

TONY J. SVEJCAR

\section{Abstract}

Burning on good to excellent condition tallgrass prairie in central Oklahoma yielded resulta which visually appeared much greater than would be expected from previous burning research. Therefore, a study was designed to quantify the effect of burning on plant and livestock responses. During 1984-1986, average daily gains of stocker cattle were monitored from late May to midOctober in replicated burned and unburned pastures. Stocking rates varied from 0.8 to $1.5 \mathrm{hn}$ per animal depending on initial animal weights. Fistulated cattle were used to monitor diet quality on the pastures. Standing crops were messured at the end of the growing season (early October) in exclosures, and at the end of the grazing period (late October) in the pastures. Animal performance was improved by burning during the early part of the grazing season, and over the season animal production per ha averaged $11.2 \mathrm{~kg}$ higher on burned compared to unburned pastures. Dietary crude protein tended to be higher on unburned compared to burned pastures, but the opposite was true for in vitro organic matter digestibility. Standing crop remaining after the graxing period averaged 4,304 and 2,539 $\mathrm{kg} / \mathrm{ha}$ for burned and unburned pastures, respectively. Standing crop was $57 \%$ higher in burned compared to unburned exclosures. Burning caused a shift in species composition to favor tallgrass species and lower production of weedy forbs in both exclosures and grazed pastures.

Key Words: preacribed burningeforagequalty, com munity compoition

The use of prescribed burning for manipulation of range vegetation has gained wider acceptance in recent years. Vegetation changes associated with burning have been documented in a number of ecosystems (Wright and Bailey 1982). Responses tend to be ecosystem-specific and are further influenced by timing of the burn, nature of the fire, environmental conditions (especially precipitation) during the year of burning, management after burning, site, and species composition. Considerably less information exists on the influence of burning on livestock performance. However, research from the Flint Hills of Kansas (Launchbaugh and Owensby 1978), timbered range in the southeastern U.S. (Hilman and Hughes 1965), the Edwards Plateau in Texas (McGinty et al. 1983), and the Texas Coastal Prairie (Angell et al. 1986) all show that burning can improve livestock performance.

The majority of research on burning response of tallgrass prairie has been conducted in Kansas. Generally, late spring (about 1 May) burning has yielded the most desirable results compared to other burn dates in terms of forage production and species composition. However, late spring burning has been shown to decrease (Aldous 1934), have no effect on (Launchbaugh and Owensby 1978), or increase (Towne and Owensby 1984; Knapp 1984, 1985) production of tallgrass prairie species. Burning has been studied in Oklahoma; however, the burns were generally not timed to obtain

\footnotetext{
Author is range scientist, USDA/ARS, 920 Valley Road, Reno, Nevada 89512. A the time of the research, he was research agronomist, USDA/ARS, Forage and Livestock Research Laboratory, El Reno, Oklahoma 73036.

The author thanks Jim Browning, Bobby Handke, Wes Jackson, Jim Trent, and Dr. Michael Zavy for assistance during the study. Drs. Robert Gillen, Wayne Leininger, and an anonymous reviewer provided constructive comments on earlier versions of the manuscript.

Manuscript accepted 24 August 1988.
}

maximum forage production (e.g., Adams et al. 1982, Rice and Parenti 1978, Kelting 1957), or burning was intended to improve poor to fair condition tallgrass prairie (Graves and McMurphy 1969). Results from management burns conducted on good to excellent condition tallgrass prairie in central Oklahoma suggested that positive response to fire was greater than might be expected. Burning of tallgrass prairie is used as a management tool in some parts of Oklahoma, especially the northcentral portion of the state, but data detailing the response of livestock to these prescribed burns are not available in the literature. This study was conducted to assess the impact of burning on seasonal trends in diet quality and livestock performance on native tallgrass prairie in central Oklahoma.

\section{Study Site}

The study was conducted from 1984 to 1986 at the USDA/ARS Forage and Livestock Research Laboratory near El Reno, Oklahoma. Vegetation on the study site was typical of good condition tallgrass prairie, with big bluestem (Andropogon gerardii Vitman var. gerardii), Indiangrass (Sorghastrum nutans L.), and little bluestem (Schizachyrium scoparium [Michx.] Nash) as dominants. Soils were silt loams classified as either Udic Paleustolls or Pachic Arguistolls, tended to be well drained, relatively deep (150 $\mathrm{cm}$ ), and had high available water capacity (Fisher and Swafford 1976). Mean annual precipitation is $762 \mathrm{~mm}$, of which $68 \%$ (520 mm) occurs during the April through September growing season. Precipitation was below average during 1984, when yearly and growing season totals were 724 and $349 \mathrm{~mm}$, respectively. Precipitation was above average in 1985 (annual $=969 \mathrm{~mm}$, growing season $=602 \mathrm{~mm}$ ) and 1986 (annual $=1,108 \mathrm{~mm}$, growing season = $817 \mathrm{~mm}$ ). Mean annual temperature is $15.6^{\circ} \mathrm{C}$. The site has had a history of moderate grazing, but had not been burned for at least 15 years prior to the initiation of the study.

\section{Materiabs and Methods}

Two adjacent pastures, 37 and 53 ha in size, were used in the study. Each pasture was split, and at random half was assigned to either burning or control treatments. Pastures were treated as blocks, and treatment/block combinations will subsequently be referred to as paddocks. Burning was conducted on 23 April 1984; 10 April 1985; and 7 April 1986. Paddocks were burned when big bluestem had 2 to $4 \mathrm{~cm}$ of leaf growth. This criteria was selected because it ensured that ambient conditions would support growth of tallgrass species immediately following burning. At the beginning of the grazing period sward height was about 15 to $22 \mathrm{~cm}$. Each paddock was stocked at $1.5 \mathrm{ha} /$ animal from 13 June to 11 October 1984 and 19 May to 16 October 1985 . Heifers with initial average weights of 425 and $460 \mathrm{~kg}$ were used in 1984 and 1985, respectively. Steers averaging $190 \mathrm{~kg}$ were stocked at $1.2 \mathrm{ha} /$ animal from 19 May to $1 \mathrm{July}$, and $0.8 \mathrm{ha} /$ animal from 2 July to 18 September 1986. Average daily gain (ADG) was calculated on the steers initially placed in the paddocks; the additional animals were used to adjust the stocking rate to more nearly match available forage. Animals were penned during late afternoon and weighed 


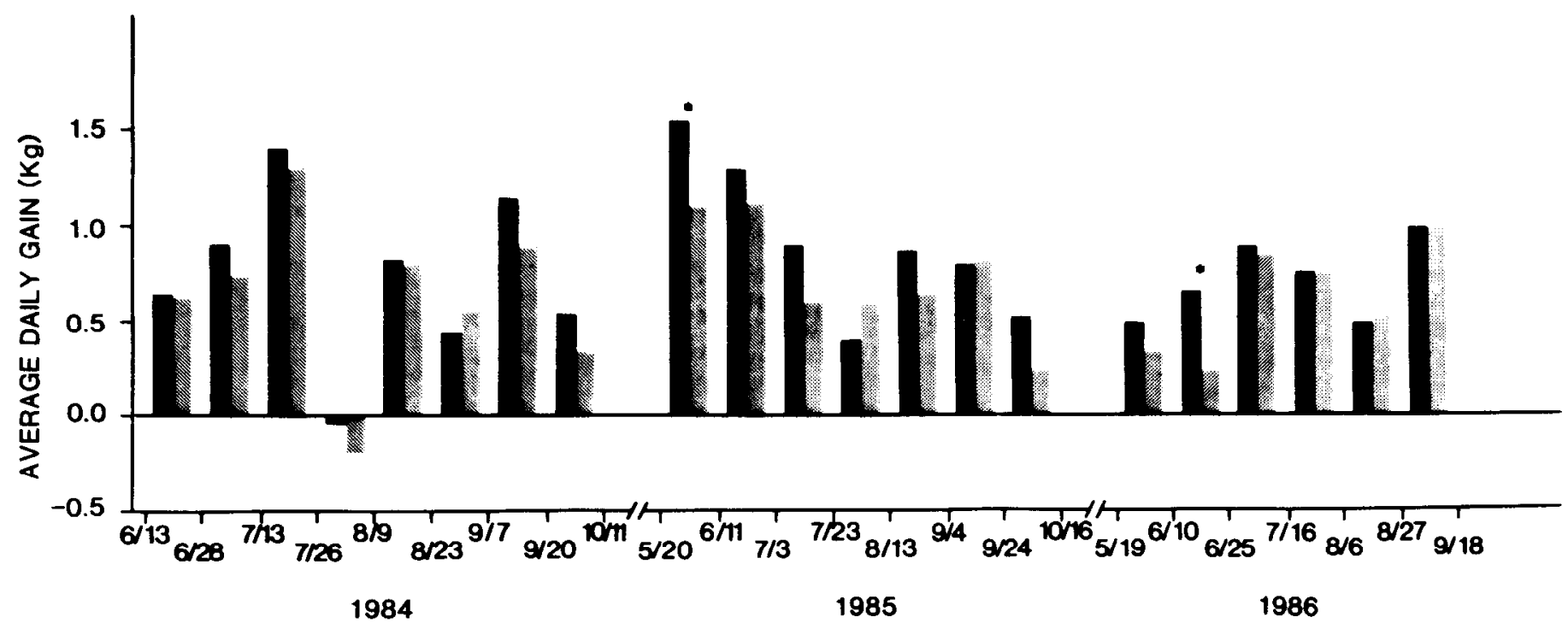

Fig. 1. Average daily gains (kg) of stocker cattle grazing burned (solid bar) or unburned (striped bar) tallgrass prairie. Weigh periods averaged 14 days in 1984, and 21 days in 1985 and 1986. Asterisks indicate treatments were different at the $\mathrm{p}<0.05$ level.

the following morning to provide a 16 -hr shrink period. Weights were taken at 14-day intervals in 1984 and about 21 -day intervals in 1985 and 1986 . During the 30 days preceding the study period both heifers and steers grazed unburned native range and were supplemented with Old World bluestem (Bothriochloa sp.) hay at about $0.7 \%$ of body weight per day.

Esophageally fistulated heifers were used to assess forage quality of the paddocks. Sampling was conducted in the early morning, with 4 heifers grazing one treatment and then the other within a block on a given sampling date. The second block was sampled in the same manner the following day. Order of sampling for treatments and blocks was random. Extrusa samples were frozen at $-20^{\circ} \mathrm{C}$, freeze-dried, and ground to pass through a $2-\mathrm{mm}$ screen in a cyclone mill (U-D Corp., Ft. Collins, Colorado) ${ }^{1}$. Samples were analyzed for crude protein (CP) with a micro-Kjeldahl system, and for in vitro organic matter digestibility (IVOMD) using a modified Tilley and Terry (1963) procedure. Incubation periods were $48 \mathrm{~h}$ in rumen fluid and $24 \mathrm{~h}$ in pepsin.

Paddocks were assessed for standing crop at the end of each grazing period. Forty randomly located $.25-\mathrm{m}^{2}$ quadrats per paddock were clipped to ground level and samples grouped into the following categories: (1) tallgrasses, big bluestem and Indiangrass; (2) midgrasses, little bluestem and tall dropseed (Sporobolus asper [Michx.] Kunth); (3) weedy forbs, western ragweed (Ambrosia psilostachya DC.) and Louisiana sagewort (Artemisia ludoviciana Nutt.); and (4) other species. Samples were dried at $55^{\circ} \mathrm{C}$ for $72 \mathrm{~h}$ and weighed. Three exclosures $(10 \times 60 \mathrm{~m})$ were constructed along the burned/unburned fenceline within each block. Standing crop was also assessed in these exclosures. Four quadrats per treatment / exclosure combination were sampled during 1984, and 6 quadrats per treatment/exclosure combination were sampled in 1985. Phytomass within each quadrat was clipped to ground level and separated into big bluestem, little bluestem, Indiangrass, western ragweed, sagewort, and other. Samples were dried at $55^{\circ} \mathrm{C}$ for $62 \mathrm{hr}$ and weighed.

Data from the grazing study were analyzed using two-way (sampling date $X$ treatment) analysis of variance with a randomized block design. Because treatment by time interactions are common in studies such as this, treatment comparisons were also made

${ }^{1}$ Mention of tradename does not indicate endorsement by USDA. within each sampling date. Standing crop remaining after grazing was analyzed using one-way analysis of variance with 2 blocks, and data from the exclosures were analyzed with one-way analysis of variance using exclosures as blocks. All analyses were conducted using the Statistical Analysis System (SAS). Unless otherwise designated, statistical differences refer to the $p<0.05$ level of probability.

\section{Results}

Average daily gain was generally higher on burned compared to unburned pastures during late-May to early-July, although treatments were statistically different for only 2 weigh periods (Fig. 1). From mid-July to the end of the grazing period, results were variable, but when averaged over this period, ADG for the 2 treatments was similar. Total gain per head and total gain per ha over the grazing season averaged 15.2 and $11.2 \mathrm{~kg}$ higher, respectively, on burned compared to unburned pastures (Table 1). There were significant treatment by year interactions for total gain per head. The interaction apparently resulted from the greater treatment response in 1985 compared to 1984 and 1986. Total gain per hectare was not analyzed statistically because only 1 value per pasture was generated, resulting in a very small actual sample size and no estimate of variation within a pasture.

There was a significant treatment by sampling date interaction

Table 1. Total gain per head (kg) and total gain per hectare $(\mathrm{kg} / \mathrm{ha})$ on burned and unburned tallgrass prairie. Total gain per head was analyzed statistically ( $n=24$ for 1984 and 1985; $n=43$ for 1986), but total gain per hectare was not.

\begin{tabular}{lllll}
\hline \hline & 1984 & 1985 & 1986 & $\begin{array}{c}\text { 3-Year } \\
\text { Average }\end{array}$ \\
\hline Total Gain/Head & & & & \\
$\quad$ Unburned & 67.7 & 109.5 & 76.2 & 84.6 \\
$\quad$ Burned & 77.7 & $136.0^{*}$ & 85.5 & 99.7 \\
$\begin{array}{l}\text { Total Gain/Hectare } \\
\text { Unburned }\end{array}$ & 45.1 & 73.0 & 76.2 & 64.8 \\
$\quad$ Burned & 51.8 & 90.6 & 85.5 & 76.0 \\
\hline
\end{tabular}

*Indicates significance at the $p<0.05$ level. 


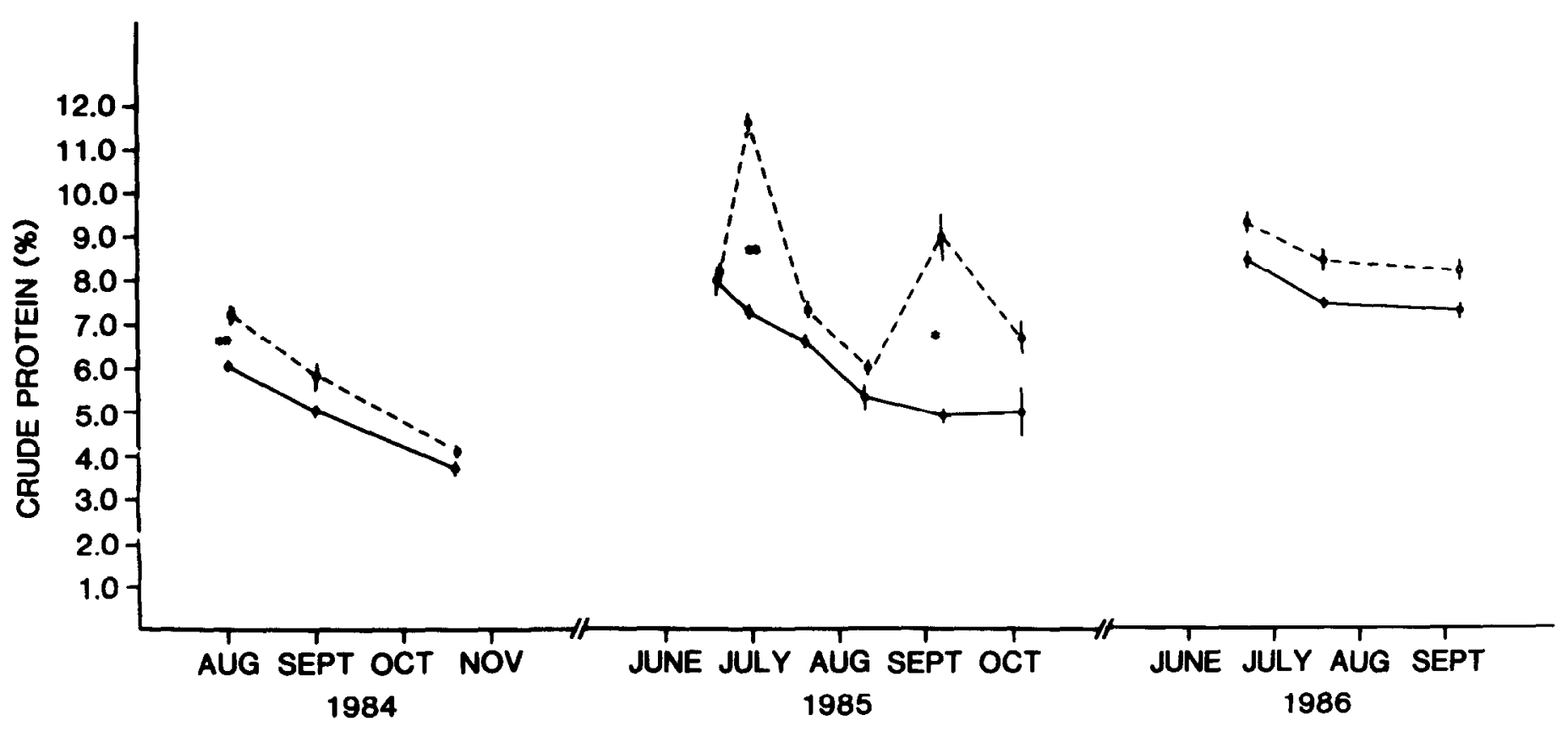

Fig. 2. Dietary crude protein in burned (solid lines) and unburned (dashed lines) pastures. Vertical bars are \pm 1 standard error of the mean. Asterisks indicate treatments were different at the $\mathrm{p}<0.05(*)$ or $\mathrm{p}<0.01(*)$ ) level.

for both CP and IVOMD during 1984 and 1985 (Fig. 2 and 3). Neither interaction with time nor treatment main effect were significant for CP or IVOMD during 1986. The trend was for IVOMD to be slightly higher on burned compared to unburned pastures during the first half of the grazing period, but treatment values were similar during the second half. Crude protein, on the other hand, tended to be higher on unburned compared to burned pastures on most sampling dates.

There was a treatment by year interaction for total standing crop remaining after grazing. The interaction resulted from the fact that treatments were not statistically different in 1984, but were different in 1985 and 1986 (Table 2). The most prominent impact of burning on individual species classes was an increase in the tallgrasses and decrease in weedy species relative to the unburned control. The same results were evident in the exclosures; i.e., standing crop was greater with burning, big bluestem increased and western ragweed and sagewort decreased in composition (Table 3). There was no treatment by year interaction for total standing crop and the treatment effect was significant $(p=0.005)$.

\section{Discussion}

The beneficial effect of burning on animal performance was most evident during the early portion of the grazing period (Fig. 1). This result is in agreement with Anderson et al. (1970) who found that late-spring burning of tallgrass prairie in Kansas increased ADG in May and June, but not in July, August, or September. Thus, the period of improved animal performance as a result of burning coincides with the time of active growth for the tallgrass species. The tallgrasses are generally active from April to mid-July

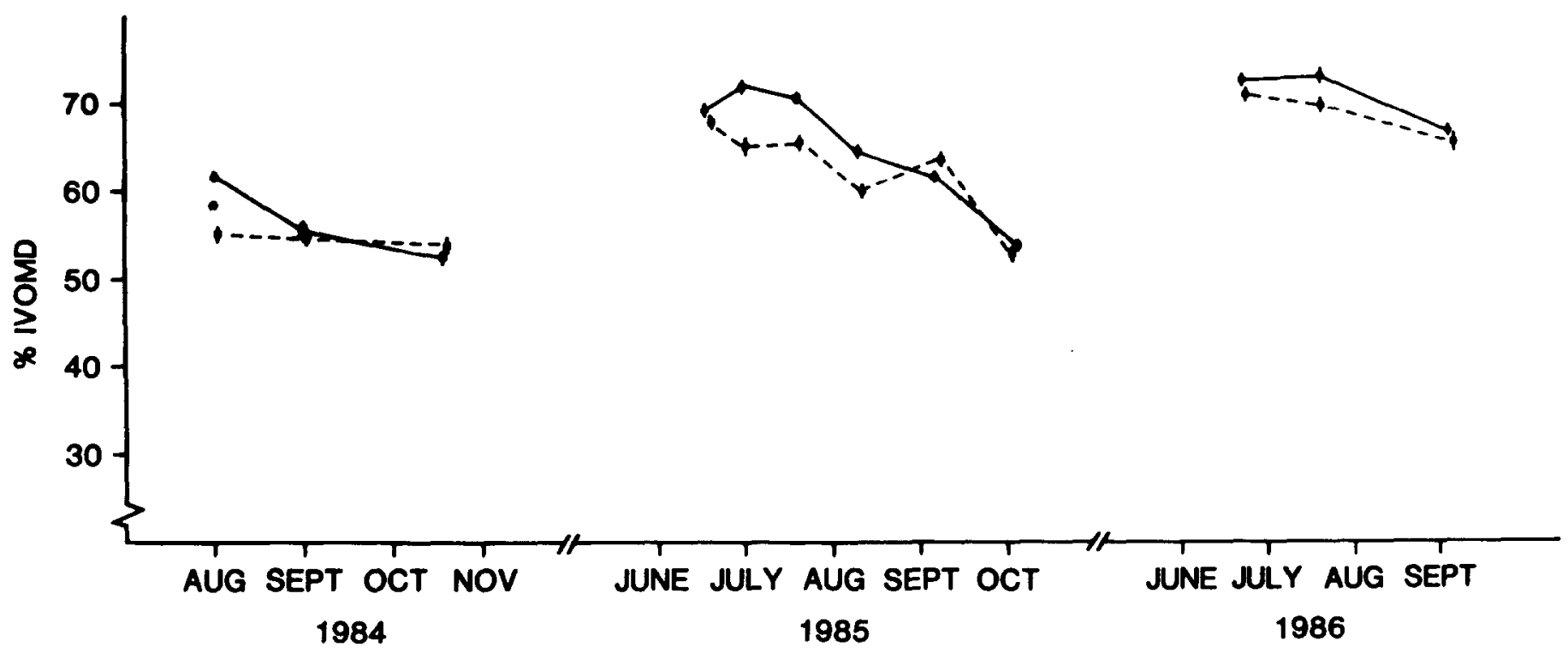

Fis. 3. In vitro organic matter digestibility of diets in burned (solid lines) and unburned (dashed lines) pastures. Vertical bars are \pm 1 standard error of the mean. Asterisks indicate treatments were different at the $\mathrm{p}<0.05$ level. 
Table 2. Standing crop ( $\mathrm{k} / \mathrm{ha})$ remalning in bumed (B) and unburned (U) paddocks at the end of the graxing period ( $n=80)$.

\begin{tabular}{|c|c|c|c|c|c|c|c|c|c|}
\hline & \multicolumn{3}{|c|}{1984} & \multicolumn{3}{|c|}{1985} & \multicolumn{3}{|c|}{1986} \\
\hline & B & $\mathbf{U}$ & $\mathbf{P}^{\prime}$ & B & $\mathbf{U}$ & $\mathbf{P}$ & B & $\mathrm{U}$ & $\mathbf{P}$ \\
\hline $\begin{array}{l}\text { Tallgrasses } \\
\text { Midgrasses } \\
\text { Weeds } \\
\text { Other } \\
\text { Total }\end{array}$ & $\begin{array}{r}2648 \\
498 \\
92 \\
232 \\
3470\end{array}$ & $\begin{array}{r}1304 \\
1224 \\
240 \\
208 \\
2976\end{array}$ & $\begin{array}{l}.10 \\
.20 \\
.19 \\
.75 \\
.35\end{array}$ & $\begin{array}{r}3884 \\
460 \\
48 \\
108 \\
4500\end{array}$ & \begin{tabular}{|c|}
744 \\
688 \\
368 \\
144 \\
1944
\end{tabular} & $\begin{array}{l}.05 \\
.08 \\
.29 \\
.19 \\
.05\end{array}$ & $\begin{array}{c}3546 \\
1221 \\
90 \\
84 \\
4941\end{array}$ & $\begin{array}{r}1072 \\
1031 \\
417 \\
174 \\
2694\end{array}$ & $\begin{array}{l}.07 \\
.80 \\
.12 \\
.18 \\
.009\end{array}$ \\
\hline
\end{tabular}

IProbability $>$ F that the treatments are different.

at which point soil moisture is usually depleted and ambient temperatures often reach $35^{\circ} \mathrm{C}$ or higher (Svejcar and Browning 1988, Knapp 1984). Wright and Bailey (1982) suggested that burning in the southern Great Plains results in earlier growth of forage and improved palatability and utilization by livestock. But as active growth ceases, the potential of these effects to maintain the advantage in burned pastures declines. The grazing initiation dates used in this study were conservative, i.e., grazing did not commence as early as it might have. Because burning improves ADG more early compared to late in the season, the difference between treatments would probably have been greater if grazing was initiated earlier.

Table 3. Species and total standing crops (kg/ha) from burned and unburned tallgrass prairie exclosures ( $n=24$ in $1984 n=36$ in 1985). There was no significant treatment by year interaction for total standing crop ( $p>0.05)$ and the treatment efiect was significant $(p=0.005)$.

\begin{tabular}{lccccc}
\hline & \multicolumn{2}{c}{1984} & & \multicolumn{2}{c}{1985} \\
\cline { 2 - 3 } \cline { 5 - 6 } Species & Burned & U̇nburned & & Burned & Unburned \\
\hline Big bluestem & 3853 & 1472 & & 3031 & 1390 \\
Little bluestem & 148 & 411 & & 199 & 116 \\
Indiangrass & 543 & 205 & & 1242 & 637 \\
Western ragweed & 148 & 445 & & 50 & 145 \\
Sagewort & 9 & 171 & & 3 & 116 \\
Other & 240 & 720 & & 445 & 492 \\
Total standing crop & 4940 & 3424 & & 4968 & 2896 \\
\hline
\end{tabular}

Cattle grazing burned pastures tended to have lower dietary CP compared to those grazing unburned pasture, in spite of the fact that early growth big bluestem leaves had higher CP under burned relative to unburned condition (Svejcar and Browning 1988). Fistula sampling wasn't conducted earlier than mid-June, and thus the period during which burning would improve the level of dietary CP may have been missed. However, McGinty et al. (1983) found that dietary CP was similar among burned and unburned treatments early in the grazing season, but lower in burned pastures during the latter part of the grazing period, in spite of the fact that hand clipped samples from burned pastures had higher CP levels than samples from unburned pastures. They attributed the higher dietary $\mathrm{CP}$ in unburned pastures to higher use of forbs relative to burned pastures. There were 2 sharp peaks in level of dietary CP in control pastures during 1985 (Fig. 2). These probably were caused by a shift in diet composition, since a sudden increase in CP of the dominant tallgrasses would be very unlikely. Woolfolk et al. (1975) measured slightly higher dietary CP in burned relative to unburned tallgrass prairie in Kansas, and Allen et al. (1976) found that burning resulted in increased CP content of big and little bluestem. Thus, it appears that burning initially causes increased CP content of the grasses, but may lower dietary CP because intake of forbs is reduced. Variation in results across locations may depend on the importance of forbs to diet quality at the various sites.

In the present study, there tended to be an improvement in diet digestibility with burning during the first half of the grazing period (Fig. 3). Although treatment differences were seldom significant on a given date, and treatments interacted with time, the slight improvement in digestibility early in the grazing period may have been sufficient to improve animal performance. Prior research indicates that diet digestibility is either unaffected (Woolfolk et al. 1975), or improved (McGinty et al. 1983, Smith et al. 1960) by burning grasslands in the southern Great Plains. When entire plants were clipped to ground level and analyzed, both big and little bluestem had higher apparent digestibility under burned compared to unburned conditions (Allen et al. 1976). Another potentially important factor is the proportion of live to dead phytomass in the diet. Burning removes residual dead material that cattle are not able to selectively exclude in unburned pastures. McGinty et al. (1983) found that early in the grazing period diets from unburned pastures were higher in dead phytomass than those from burned pastures, but as \% dead phytomass increased over the season, treatment differences became very small. Digestibility responses to burning may be positive or neutral, depending on the year and/or specific grassland in question. Potential factors influencing diet digestibility are similar to those influencing dietary CP and include: (1) impact of burning on the quality of dominant species, (2) shifts in diet resulting from burning, and (3) influence of burning on sward structure, in particular removal of dead material.

Animal production over the grazing season was $11.2 \mathrm{~kg} / \mathrm{ha}$ or $17 \%$ higher on burned compared to unburned paddocks (Table 1). The improvement in gain per ha is similar to the $11.8 \mathrm{~kg} / \mathrm{ha}$ improvement with late spring burning reported in Kansas (Launchbaugh and Owensby 1978). Gain per ha is influenced by stocking rate, time and duration of grazing, and class of livestock; thus, comparisons of cattle gains can be difficult to interpret. Launchbaugh and Owensby (1978) reported that forage production was similar on late-spring burned and unburned tallgrass prairie, whereas during the first two years of this study, burning increased standing crops in exclosures 57\% relative to unburned conditions (Table 3). In the present study, there was also considerably more standing crop remaining after the grazing season on burned pastures compared to the results from Kansas. Standing crop remaining after grazing on an upland tallgrass prairie site in Kansas was 2,723 and $2,256 \mathrm{~kg} / \mathrm{ha}$ for unburned and burned pastures, respectively (Anderson et al. 1970), as opposed to 2,539 and 4,304 kg/ ha, for unburned and burned prairie, respectively, in the present study. Thus, tallgrass prairie in central Oklahoma exhibited a more positive response to burning than did tallgrass prairie in Kansas. However, the study site has higher production potential than many tallgrass prairie sites in Oklahoma (Bob Gillen, personal communication), and could have higher production potential than the sites studied in Kansas. Two additional points should be considered in interpreting these results: (1) the tallgrass prairie in the present 
study was initially in good to excellent condition, and (2) 2 of 3 study years were above average in precipitation. Further research will be necessary to determine the impact of burning on poor to fair condition prairie or during dry years.

The economics of burning are quite favorable under the conditions of this study. The cost of burning on tallgrass prairie in central Oklahoma is about \$5/ha (Dale Rollins, personal communication), and in this study, the average increase in animal production from burning was $11.2 \mathrm{~kg} / \mathrm{ha}$. Thus, if cattle were sold at the end of the grazing period for $\$ 1.32$ per $\mathrm{kg}$ ( $\$ 0.60$ per pound), the increased revenue from burning would be about $\$ 15$ per ha. The net return from burning would be $\$ 10$ per ha. This calculation is very simplistic and does not account for the extra forage remaining at the end of the grazing season on burned pastures. The extra forage could be used to winter cows or could be consumed during the grazing period if stocking rates were increased on burned paddocks. Bernardo et al. (1988) analyzed the economics of burning on tallgrass prairie infested with eastern red cedar (Juniperus virginiana $\mathrm{L}$.); they also concluded that prescribed burning was economically favorable. Thus, burning proved to be an effective management tool on good condition tallgrass prairie in central Oklahoma. Burning improved production of tallgrass species and livestock, and calculations indicate a positive return on stocker operations.

\section{Literature Cited}

Adams, D.E., R.C. Anderson, and S.L. Collins. 1982. Differential response of woody and herbaceous species to summer and winter burning in an Oklahoma grassland. Southwestern Natur. 27:55-61.

Aldous, A.E. 1934. Effect of burning on Kansas bluestem pastures. Kansas Agr. Exp. Sta. Tech. Bull. 38.

Allen, L.J., L.H. Harbers, R.S. Schalles, C.E. Owenaby, and E.F. Smith. 1976. Range burning and fertilizing related to nutritive value of bluestem grass. J. Range Manage. 29:306-308.

Anderson, K.L., E.F. Smith, and C.E. Owensby. 1970. Burning bluestem. J. Range Manage. 23:81-91.

Angell, R.F., J.W. Stuth, and D.L. Drawe. 1986. Diets and liveweight changes of cattle grazing fall burned Gulf cordgrass. J. Range Manage. 39:233-236.
Bernardo, D.J., D.M. Engle, and E.T. MeCollum. 1988. An economic assessment of risk and returns from prescribed burning on tallgrass prairie J. Range Manage. 41:178-183.

Ftsher, C.F., and B. Swafford. 1976. Soil survey of Canadian County, Oklahoma. USDA Agr. Soil Conserv. Serv. and Okla. State Univ. Agr. Exp. Sta.

Graves, J.E., and W.E. McMurphy. 1969. Burning and fertilization for range improvement in central Oklahoma. J. Range Manage. 22:165-168.

Hilman, J.B., and R.H. Hughes. 1965. Fire and forage in the wiregrass type. J. Range Manage. 18:251-254.

Kelting, R.W. 1957. Winter burning in central Oklahoma grassland. Ecology 38:520-522.

Knapp, A.K. 1984. Post-burn differences in solar radiation, leaf temperature, and water stress influencing production in a lowland tallgrass prairie. Amer. J. Bot. 71:220-227.

Knapp, A.K. 1985. Effect of fire and drought on the ecophysiology of Andropogon gerardii and Panicum virgatum in a tallgrass prairie. Ecology 66:1309-1320.

Launchbaugh, J.L., and C.E. Owensby. 1978. Kansas rangelands: Their management based on a half century of research. Kansas Agr. Exp. Sta. Bull. $622.56 \mathrm{p}$.

McGinty, A., F.E. Smeins, and L.B. Merrly. 1983. Influence of spring burning on cattle diets and performance on the Edwards Plateau. J. Range Manage. 36:175-178.

Rice, E.L., and R.L. Parenti. 1978. Causes of decreases in productivity in undisturbed tallgrass prairie. Amer. J. Bot. 65:1091-1097.

Smith, E.F., V.A. Young, K.L. Anderson, S.W. Rullifson, and S.N. Rogers. 1960. The digestibility of forage on burned and nonburned bluestem pasture as determined with grazing animals. J. Anim. Sci. 19:388-391.

Svejear, T.J., and J.A. Browning. 1988. Growth and gas exchange of Andropogan gerardii as influenced by burning. J. Range Manage. 41:239-244.

Tilley, J.M., and R.A. Terry. 1963. A two-stage technique for the in vitro digestion of forage crops. J. Brit. Grassl. Soc. 18:104-111.

Towne, G., and C. Owenoby. 1984. Long-term effects of annual burning at different dates in ungrazed Kansas tallgrass prairie. J. Range Manage. 37:392-397.

Woolfolk, J.S., E.F. Smith, R.S. Schalles, B.E. Brent, L.H. Harbers, and C.E. Owensby. 1975. Effects of nitrogen fertilization and late-spring burning of bluestem range on diet and performance of steers. J. Range Manage. 28:190-193.

Wright, H.A., and A.W. Balley. 1982. Fire ecology. John Wiley and Sons, New York. 